\title{
Determinants of Income of Poor Women-Headed Households in Madiun City
}

\author{
By: \\ Sodik Dwi Purnomo \\ Politeknik Indonesia Madiun \\ Email: sodikdwipurnomo@yahoo.com
}

\begin{abstract}
The number of poor households headed by women in Madiun City is more than that of poor households with male family heads. This study is aimed to analyze the effect of the level of education, number of family members, age, number of work hours, and type of work against the income of poor woman as a head of the family in the City of Madiun. Population in this research is the poor household has headed poor women in the City of Madiun and in the sampling uses the simple random sampling method, with the result of 98 poor households. The data analysis technique uses a multiple linear regression with Ordinary Least Square method (OLS). The analysis result showed that the level of education, number of family members and the number of work hours has a positive and significant impact on the income of low-income families while the age and type of work are not significantly affecting the income of poor women as heads of households in the City of Madiun.
\end{abstract}

Keywords: Poverty, Head of Household's Women, Income, Education, Number of Family Member, Number of Work Hours, Type of Work.

\begin{abstract}
ABSTRAK
Jumlah rumah tangga miskin yang berkepala keluarga wanita di Kota Madiun lebih banyak dibandingkan dengan rumah tangga miskin yang berkepala keluarga laki-laki. Penelitian ini bertujuan untuk menganalisis pengaruh tingkat pendidikan, jumlah anggota keluarga, usia, jumlah jam kerja, dan jenis pekerjaan terhadap pendapatan kepala keluarga wanita miskin di Kota Madiun. Populasi penelitian ini adalah rumah tangga miskin yang berkepala keluarga wanita di Kota Madiun. Pengambilan sampe sebanyak 98 rumah tanggamiskin dilakukan denga metode simple random sampling. Teknik analisis data menggunakan regresilinier berganda dengan metode Ordinary Least Square (OLS). Hasil analisis menunjukkan bahwa tingkat pendidikan, jumlah anggota keluarga dan jumlah jam kerja mempunyai pengaruh positifdan signifikan terhadap pendapatan keluarga miskin sedangkan usia dan jenis pekerjaan tidak berpengaruh signifikan terhadap pendapatan kepala keluarga wanita miskin di Kota Madiun.
\end{abstract}

Kata kunci: Kemiskinan, Kepala Keluarga Wanita, Pendapatan, Pendidikan, Jumlah Anggota Keluarga, Jumlah Jam Kerja, Jenis Pekerjaan.

\section{INTRODUCTION}

Economic development in Indonesia still faces the problem of high numbers of poverty. Poverty is characterized by low income, so it cannot meet basic needs. Generally, in developing countries, lowincome problems and poverty are the main problems in economic development. Thus, in the objectives of economic development, these two things are always stated together so that they become one sentence that is an increase in opinion and poverty reduction (Arsyad, 2010).

Poverty is a complex problem because it involves interrelated factors, including income level, health, education, access to goods and services, geographical location, gender and environmental 
conditions (Kuncoro, 2010). The complexity of this poverty problem makes poverty alleviation efforts quite tricky. Various policies such as Presidential Instruction for Disadvantaged Villages (IPDT), Social Safety Net Program (JPS), Special Market Operations (OPK), District Development Programs (PPK), as well as giving rise to needy families (RASKIN), Direct Cash Assistance (BLT), People's Business Credit (KUR), Smart Indonesia Card (KIP), Healthy Indonesia Card (KIS), which is intended for the poor family sector and School Operational Assistance (BOS) given to students who are less able to study and other assistance is expected to reduce the amount of poverty in realizing community welfare (Ministry of Social Affairs, 2015).

Poverty, as stated in the National Medium Term Development Plan (RPJMN, 2009-2014), is not only understood as an economic incapacity, but also a failure to fulfill fundamental rights and differences in treatment for a person or group of people in living their lives with dignity. Fundamental rights that are generally recognized include the fulfillment of food, health, employment, housing, clean water, land, natural resources, and the environment, and a sense of security from the treatment or threat of violence (National Development Planning Agency, 2015).

Poverty and low income per capita are also a causal relationship meaning high poverty rates occur due to low per capita income. Low per capita income occurs because per capita investment is also low. Low per capita investment levels are caused by low per capita domestic demand as well, and this happens because of the high level of poverty and so on, thus forming a circle of poverty (Nurkse in Kuncoro, 2010).

The problem of poverty in Indonesia is not only a rural problem but also an urban problem. Suharto (2009) suggests that the problem of poverty in urban areas is an inherent and complex problem. Social problems in urban areas include crime, congestion, social irregularities and violations of prevailing norms in society.

Indonesia is one of the developing countries in the Southeast Asia region and has a vast population, but the population is also relatively poor. The number of poverty in Indonesia is shown in Table 1.

Table 1. Number of Households with Female Families in Indonesia, 2013-2015

\begin{tabular}{ccc}
\hline Year & Number of Poverty (Million People) & $(\%)$ \\
\hline 2008 & 34,96 & 15,42 \\
2009 & 32,52 & 14,15 \\
2010 & 31,02 & 13,33 \\
2011 & 29,89 & 12,36 \\
2012 & 29,25 & 11,96 \\
2013 & 28,17 & 11,41 \\
2014 & 28,28 & 11,25 \\
2015 & 28,59 & 11,54 \\
\hline
\end{tabular}

Source: BPS, 2015

Table 1 shows that the number of poverty in Indonesia decreased from 2008 to 2013, but in 2014 to 2015 increased. Poverty increased in 2015 due to rising prices of fuel oil (BBM). This has caused a decline in the purchasing power of the community because all the staple goods get the impact of rising fuel prices such as rising prices of basic foods and rising production costs, causing people's purchasing power to decline and impacting the increase in poverty (detik.com October 4, 2015).

Household poverty is not only borne by the male head of the family. This can occur due to various things such as divorce, or the husband dies which allows a woman to be the head of the family. Huston (1979) explains that women have an essential role in the family consistency urban community. Women contribute a very high labor force in the form of domestic labor and family livelihood. However, this is not balanced with treatment and recognition as well as access to 
information and technology that are equal to men, so it is not surprising that ultimately not prosperity is achieved but sustainable poverty (University of Indonesia Women's and Gender Study Center, 2007).

Kurniasih (2013) in the National Team for the Acceleration of Poverty Reduction (TNP2K) explained that the poverty ratio of female heads of households with male family heads was almost the same, but female heads of household were more vulnerable to economic turmoil such as rising prices. One of the factors behind this is that many female heads of household work in the informal sector where there is no guarantee of stability, such as the absence of a pension and the possibility of sudden dismissal.

The following is a table that shows the number of female-headed households in Indonesia:

Table 2. Number of Households with Female Families in Indonesia, 2013-2015

\begin{tabular}{ccccc}
\hline \multirow{2}{*}{ Year } & \multicolumn{2}{c}{ Poor Residents } & \multicolumn{2}{c}{ Non-Poor Residents } \\
\cline { 2 - 5 } & $\begin{array}{c}\text { Amount } \\
\text { (Million People) }\end{array}$ & $(\%)$ & $\begin{array}{c}\text { Amount } \\
\text { (Million People) }\end{array}$ & $(\%)$ \\
\hline 2013 & 14,41 & 48,65 & 15,21 & 51,35 \\
2014 & 14,49 & 49,90 & 14,55 & 50,10 \\
2015 & 14,61 & 52,73 & 13,10 & 47,27 \\
\hline
\end{tabular}

Source: BPS, 2015

Table 2. shows that the number of female-headed households from 2013 to 2015 has increased both in number and percentage. The high percentage and amount of poverty in Indonesia are caused by increases in prices of necessities and prices of fuel oil (BBM) that the government cannot control. Therefore, residents in poor, vulnerable groups can easily slip into the poor category (Liputan6.com October 15, 2015).

Kuncoro (2010) states that the level of education can influence poverty. This is because the higher the level of education of a person, the opportunity to get a decent job and income will be more accessible. The following is a table that shows the level of education of poor households headed by female families in Indonesia.

Table 3. Education Levels of Poor Women Family Heads in Indonesia, 2014-2015 (Million People)

\begin{tabular}{lcc}
\hline \multirow{2}{*}{ Level of Education } & \multicolumn{2}{c}{ Year } \\
\cline { 2 - 3 } & 2014 & 2015 \\
\hline Tidak Tamat Sekolah Dasar & 40,30 & 40,57 \\
Sekolah Dasar & 40,47 & 37,89 \\
Sekolah Menengah Pertama & 11,28 & 12,33 \\
Sekolah Menengah Atas & 7,56 & 8,56 \\
Perguruan Tinggi & 0,39 & 0,65 \\
\hline
\end{tabular}

Source: BPS, 2015

Table 3 shows that nationally the level of education of female heads of households in lowincome families is dominated by those who do not complete elementary schools, elementary schools, and junior high schools and few can complete their education in tertiary institutions.

Urban areas are areas where infrastructure and the number of job vacancies are more than in rural areas and access to meet the needs of a comfortable life so that the ease will reduce the amount of poverty in urban areas will be less. However, the reality of several cities in East Java Province such as Kota Madiun that has a higher poverty rate compared to several cities in East Java Province. The following is a table that shows the number of poverty in all cities in East Java Province. 
Table 4. Number and Percentage of Poor Residents in Several Cities in East Java Province, 2015

\begin{tabular}{clcc}
\hline No. & City & Total (People) & $(\%)$ \\
\hline 1 & Kota Surabaya & 175.700 & 6,25 \\
2 & Kota Malang & 43.500 & 5,21 \\
3 & Kota Kediri & 22.300 & 8,14 \\
4 & Kota Pasuruan & 15.100 & 7,90 \\
5 & Kota Madiun & 12.170 & 5,37 \\
6 & Kota Batu & 9.700 & 4,47 \\
7 & Kota Blitar & 9.100 & 6,75 \\
8 & Kota Mojokerto & 8.000 & 6,48 \\
\hline
\end{tabular}

Source: BPS Provinsi Jawa Timur, 2015

Table 4 shows the number and percentage of poverty in all cities in East Java Province. Madiun City occupies the fifth position of eight cities in East Java Province with a total of 12,170 people and a percentage of 5.37 percent of the total poor population in the city. Although the City of Madiun is not a city in the top three cities with the highest number and percentage of poor people in East Java Province, some things characterize poverty in Madiun City. These characteristics are that the poor are more dominated by households with female heads of households. This can be seen in the following table.

Table 5. Number of Poverty Based on Family Heads in Madiun City, 2013-2015

\begin{tabular}{ccccc}
\hline \multirow{2}{*}{ Year } & \multicolumn{2}{c}{ Male Family Head } & \multicolumn{2}{c}{ Female Family Head } \\
\cline { 2 - 5 } & $\begin{array}{c}\text { Amount } \\
\text { (People) }\end{array}$ & \multirow{2}{*}{ (\%) } & $\begin{array}{c}\text { Amount } \\
\text { (People) }\end{array}$ & $(\%)$ \\
\hline 2013 & 2.105 & 46,76 & 2.396 & 53,24 \\
2014 & 1.947 & 49,39 & 2.020 & 50,61 \\
2015 & 2.009 & 48,33 & 2.210 & 51,61 \\
\hline
\end{tabular}

Source: Badan Perencanaan dan Pembangunan (BAPPEDA) of Madiun City, Proccessed 2015

Table 5 shows that the number and percentage of poverty of female and male household heads from 2013 to 2015 fluctuated. However, poverty in Madiun City was dominated by households with female heads of households. Based on these problems, the following research questions are formulated:

(1) What is the level of education, number of family members, age, number of working hours, and types of work that affect the income of poor families with female family heads in Madiun City?

(2) Which variable has the most influence on the income of low-income families who have female heads in Madiun City?

The income of the head of a low-income family can be influenced by several factors such as level of education, number of family members, age, number of hours worked, and type of work. The lower education illustrates the quality of its human resources is low and can cause poverty. The higher a person's education, the better the chance to get a better life, because it has quality in finding work (Suryahadi and Sumarto, 2009). Based on these explanations, the following hypotheses are prepared.

$H_{1:}$ The number of working hours of the head of the family has a positive and significant effect on the income of poor female heads of household.

Poverty is also closely related to the number of family members because it describes the burden of the family. According to Jhingan (2010), population growth as a result of high births causes the burden of family life to be heavier. The burden of family life is more substantial when bearing 
relatives such as parents and relatives. Low-income families have more family members than nonpoor families. In addition to a large number of family members, there are more members of lowincome families compared to non-poor families. Based on these explanations, the following hypotheses are prepared.

$H_{2:}$ The number of family members has a positive and significant effect on the income of poor female heads of household.

Age is one indicator of determining one's work productivity. Irawan and Suparmoko (2008) said that someone who is unproductive (population aged under 15 years and over 65 years) with productive people (population aged 15-64 years) can produce well because they are young and have physical condition strong when compared to someone who has entered the age of unproductive $(\geq$ 65 years). It can be concluded that by unproductive someone will influence the income earned due to the age factor that is owned. Based on these explanations, the following hypotheses are prepared.

$H_{3:}$ The age of family heads has a positive and significant effect on the income of poor female heads of household.

In addition to several factors that have been explained above, the number of working hours can also affect the income of the heads of poor families. The number of hours worked is the time spent by someone to do work activities. With work activities one can earn wages or income, the higher a person's income level, it can be said that the person is not included in the poor family and vice versa. The number of hours worked for each person working is not the same, there are those who work part-time and some full work time according to their desires. Therefore, in providing time to work, it is not enough to pay attention to the number of hours worked per day but also needs to be considered every week (Chaer, 2009). Someone generally works on an average day is 8 hours per day or 56 hours in 1 week. Economic conditions are increasingly difficult sometimes forcing someone to get around in order to get additional income in order to cover their daily needs by increasing working hours (overtime). By increasing the working hours automatically a person earns extra income. Based on these explanations, the following hypotheses are prepared.

$H_{4:}$ The number of working hours is the variable that most influences the income of poor female heads of household.

Another factor that can affect the income of low-income families is the primary type of work in the family. The industrial and non-industrial sectors are one type of workers whose wages are uncertain due to working hours and the total units that can be produced as a reference. The main types of work in the family are reflected by the sector of work done by the head of the family, and each sector of employment has a different level of wages. Therefore, the primary type of work in the family will affect the level of income that the family will receive. Based on these explanations, the following hypotheses are prepared.

$H_{5:}$ This type of work has a positive and significant effect on the income of poor female heads of household.

\section{RESEARCH METHOD}

\section{Research Type}

This research is explanatory research, which is a study that aims to find new relationships for research problems (Arikunto, 2010). This study is oriented to analyze the factors that influence the income of the head of a poor woman in Madiun City. This study uses a survey method. The respondent uses a questionnaire. 


\section{Data Type and Resources}

Types and sources of data used in this study are secondary and primary data.

(1) Primary Data

Primary data was obtained through surveys and interviews with women who became household heads in Madiun City.

(2) Secondary Data

Secondary data was obtained through literature study, namely by reading books related to research conducted, as well as from previous studies. In this study secondary data was obtained from the Central Statistics Agency (BPS), and the Regional Planning and Development Agency (BAPPEDA) City Madiun.

\section{Definition of Operational Variable Research}

(1) The female head of the family is a woman who is based on a family card with the status of head of the family, measured by sex.

(2) Income $(Y)$ is the income received by the head of the household of poor women in Madiun City, measured in rupiah per month.

(3) Education (X1) is the length of the last education year taken by female heads of households in Madiun City, measured in years.

(4) The number of family members (X2) is the number of family members who are the dependents of female family heads in Madiun City, measured in units of the soul.

(5) Age (X3) is the age of a female family head in Madiun City, measured in years.

(6) The number of hours worked (X4) is the number of hours worked by the female head of the household to do work activities, measured in hours per month.

(7) Job Type (X6) is the type of sector of work done by female heads of households, measured by the criteria of the industrial and non-industrial sectors because no poor people work in the formal sector.

\section{Data Analysis Techniques}

To test the influence of education level variables, number of family members, age, number of hours worked, and type of work on income of poor female heads of households in Madiun City, this study used Multiple Linear Regression Method with the least squares method or Ordinary Least Square (OLS) (Arikunto, 2010) namely:

$$
\begin{gathered}
Y=f\left(X_{1}+X_{2}+X_{3}+X_{4}+\ldots \ldots+U_{n}\right) \\
\ln Y=B_{0}+B_{1} X_{1}+B_{2} X_{2}+B_{3} X_{3}+B_{4} X_{4}+B_{5} D_{1}+e .
\end{gathered}
$$

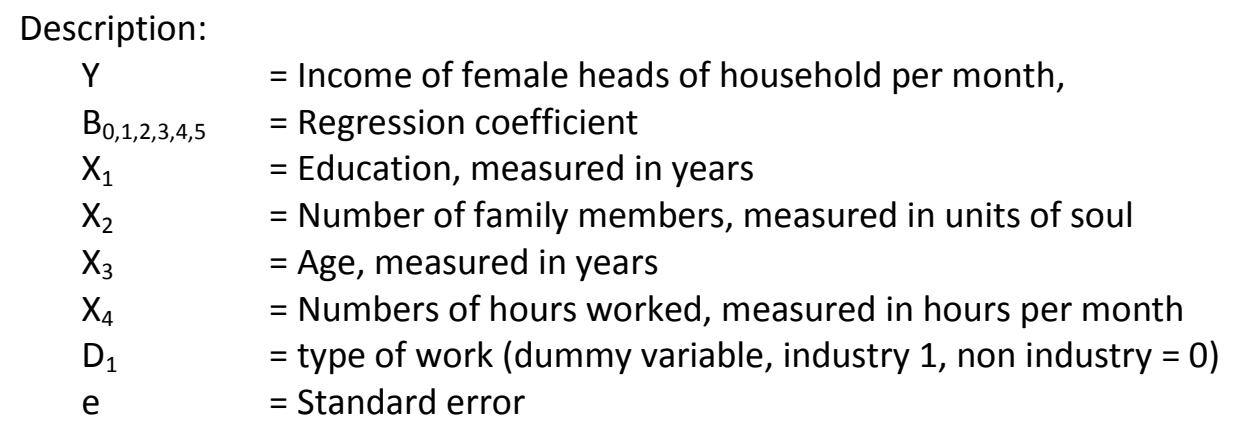

\section{Classic Assumption Test}

\section{Normality Test}

Normality test is needed in a study with the purpose of estimating and testing hypotheses. For that reason, the histogram normality test is used. If the test results show the probability value is greater than the significant level used (0.05), then the distribution of data usually spreads and vice versa. 


\section{Multicollinearity test}

Multicollinearity test is used to determine and determine whether there are relationships between two or more interrelated variables in a model. This test can be done using client detection. Client detection is done by regersing an independent variable with other independent variables. Rule of thumb by comparing the value of the $R^{2}$ model with the value $R^{2}$ Auxiliary. When the value of $R^{2}$ Auxiliary regression is greater the value of $R^{2}$ model, the model contains multicollinearity symptoms. When the value of $R^{2}$ Auxiliary regression is smaller the value $R^{2}$ model, the model does not contain symptoms.

\section{Heteroscedasticity Test}

Heteroscedasticity test is carried out to test whether in a regression model there is variance inequality of residual observations. Testing for the absence of heteroscedasticity, it can be apprehended by doing a gleser test. Accepting the classic assumption that heteroscedasticity does not occur, the probability value must be greater than alpha ( $\alpha=5 \%$ ) (Gujarati, 2008).

\section{Autocorrelation Test}

Autocorrelation Test is used to find out whether there is a deviation from the classic autocorrelation assumption, namely the correlation between residuals in observation in a regression model. Determine whether or not there is autocorrelation, a Breusch-Godfrey test method is needed. This method is based on $\mathrm{F}$ and $\mathrm{Obs} * \mathrm{R}$ - squared, where if the probability value of $\mathrm{Obs} * \mathrm{R}$-squared exceeds the level of trust, then $\mathrm{HO}$ is accepted. This means that there is no autocorrelation problem. (Gujarati, 2008).

\section{Statistical Test}

Adjusted Determination Coefficient Test $R^{2}$ adj

According to Gujarati (2008), the coefficient of determination is the amount of the contribution of the independent variable to the dependent variable. $R \wedge 2$ is a non-negative quantity with a limit of 0 $<1<0$. If the determination coefficient value is higher or close to 1 (one), then the higher the ability of the independent variable in explaining variations in changes in the dependent variable.

\section{Simultan Test (Test Statistics F)}

According to Gujarati (2008), the F test together or simultaneously is used to test the simultaneous effect of independent variables on the dependent variable. If the independent variable has a simultaneous effect on the dependent variable, the regression equation model can be said to be fit or fit.

\section{Partial Test (Test Statistics $t$ )}

Used to test the effect partially on the dependent variable. A variable will have a significant effect if the $t$ value of the variable is greater than the value of $t$ table.

\section{Elasticity Test}

The elasticity test is used to determine the independent variables with the greatest influence on the dependent variable. The equation to calculate how elastic an independent variable is to the dependent variable is as follows (Gujarati, 2008):

$$
\varepsilon_{\mathrm{i}}=\beta \mathrm{i} . \mathrm{xi}
$$

Information :

$\varepsilon i \quad:$ The elasticity of the variable to $i$

$\beta i$ : Variable regression to $i$

xi : Average independent variable to $i$ 
If the elasticity value is $>1$, then it can be said to be elastic, that is, the change in the independent variable of 1 percent results in a change in the independent variable of more than 1 percent. If the elasticity value is $0<\varepsilon<1$, then it is said to be inelastic, that is, the change in the independent variable of 1 percent results in a change in the dependent variable of less than 1 percent. So elasticity with a value of 1 is said to be unitary elasticity.

\section{RESULT AND DISCUSSION}

\section{Multiple Linear Regression}

Based on the results of multiple linear regression, the following equation is obtained:

$$
\operatorname{LnY}=11,495+0,018 X_{1}+0,120 X_{2}+0,003 X_{3}+0,006 X_{4}+0,041 X_{5}
$$

A constant value of 11.495 states that if the independent variable is considered constant, the dependent variable is 11.495 .

\section{Education Variables $\left(X_{1}\right)$}

Regression coefficient value of education variable is 0.018 which means that education variables have a positive effect on the income of poor female heads of household. This means that if the education level increases one year, it can increase the income of poor female heads of household by 0.018 percent.

Number of Family Members Variables $\left(X_{2}\right)$

Variable regression coefficient value of the number of family members of 0.120 means that the variable number of family members has a positive effect on the income of poor female heads of household. This means that if the number of family members increases by one person, it can increase the income of poor female heads of household by 0.120 percent.

Age Variables $\left(X_{3}\right)$

Regression coefficient value of the age variable is 0.003 meaning that the age variable has a positive effect on the income of poor female heads of household. This means that if the age of the head of the family increases by one year, it can increase the income of the poor woman's head of household by 0.003 percent.

Number of Hours Worked Variables $\left(X_{4}\right)$

The regression coefficient variable is the number of hours worked by 0.006 which means that the variable number of working hours has a positive effect on the income of poor female heads of household. This means that if the working hours of the head of the family increase by one hour per month, it can increase the income of the poor female head of household by 0.006 percent.

\section{Variable Jenis Pekerjaan $\left(D_{1}\right)$}

The value of the regression coefficient variable type of work is 0.041 meaning that the type of work variable has a positive effect on the income of poor female heads of household. This means that if the type of work in the industrial sector that has a dummy value of 1 , it will increase the income of the poor female head of household by 0.041 percent.

\section{Classic Assumption Test}

Normality Test

To test for normality, an analysis of the normality test histogram results from the normality test shows that the probability value is 0.101 or greater than the alphabet $(\alpha=0.05)$ so that the data of the research variable is standard. 
Multicollinearity Test

The results of the multicollinearity test showed that the variable number of hours worked, the number of family members, type of work, education, and age produced an Auxiliary value, $\leq \mathrm{R} 2$ model. So it can be interpreted that the client test results above do not occur multicollinearity.

\section{Heteroscedasticity Test}

Heteroscedasticity is a condition where the disturbance factor does not have the same or not constant variance. Testing to determine the existence of heteroscedasticity can be done by the Glejser test (Gujarati, 2008). The heteroscedasticity test using the Glejser test shows that the chisquare probability value is 0.213 . Based on the criteria that the chi-square probability value is greater than the level of significance $(\alpha=0.05)$, the above test does not have heteroscedasticity.

\section{Autocorrelation Test}

Based on the autocorrelation test using the Breusch-Godfrey test (BG). Moreover, based on the test (BG) it can be explained that the chi-square probability value (2) shows the value of 0.3535 . Based on the criteria the value of 0.3535 is greater than the level of significance of $(\alpha=0.05)$, so the test above does not have autocorrelation problems.

\section{Statistical Test}

Test of Adjusted $R$ Square (Coefficient of Determination)

From the analysis, it is known that the R2 coefficient is 0.730 according to the test criteria $R 2=0.730$, the value is close to 1 , thus the level of education, age, number of hours worked, type of work and number of family members affect the income of poor female heads of households in the City Madiun. Based on these data indicate that the independent variable can explain the percentage of 73 percent, while the remaining 26 percent change in the amount of income can be explained by other variables outside the research model such as variable capital, asset ownership, and health complaints and so forth.

\section{Simultan Test (F Test)}

From the estimation results of the regression equation model, F-count is 49.878 , while the F-table value is 2.312 at 95 percent confidence level. This shows that the calculated F-value is greater than Ftable (49.878> 2.312), meaning that $\mathrm{HO}$ is rejected. The conclusion is that the level of education, age, number of hours worked, type of work and number of family members together have a significant effect on the income of female heads of household. So the first hypothesis which states the level of education, age, number of working hours, type of work and number of family members together have a significant effect on the income of poor female heads of households in Madiun City, accepted.

\section{Parsial Test (T-test)}

From the results of the analysis using the error rate $(\alpha)=0.05$, it is known that the $t$ count value is 1.660. From the value of $t$ table, it can be explained the influence of each independent variable on the dependent variable as follows:

a) Number of Working Hours

The $t$ value of the variable number of working hours is 7.240 , and the $t$ table value is obtained for 1.660. From these results it can be seen that the value of $t$ count $>t$ table so that $\mathrm{Ha}$ is accepted, meaning the hypothesis that the variable number of working hours partially has a significant effect on the income of the head of a poor woman's family in Madiun City can be accepted.

b) Number of family members

The value of $t$ count variable number of family members amounted to 4,642 and t table value obtained at 1,660 . From these results it can be seen that the value of $t$ count $>t$ table so that $\mathrm{Ha}$ is accepted, meaning the hypothesis that the variable number of family members partially has a significant effect on income of the female head of household poor in Madiun City can be accepted. 


\section{c) Education}

$T$ value of the education variable count is 2.303 and $t$ table value is obtained at 1.660 . From these results it can be seen that the value of $t$ count> $t$ table so that $\mathrm{Ha}$ is accepted, meaning the hypothesis that partially education variables have a significant effect on the income of poor female heads of households in Madiun City acceptable.

d) Age

The $t$ value of the age variable is 1.166, and the value of the $t$ table is 1.660. From these results, it can be seen that the value of $\mathrm{t}$ count $<\mathrm{t}$ table so that $\mathrm{Ha}$ is rejected, meaning that the hypothesis that the age variable partially has no significant effect on the income of the head of the poor woman in Madiun City is rejected.

e) Type of Work

The $t$ value type of work variable is 1.166 and $t$ table value is obtained at 1.660 . From these results it can be seen that the value of $\mathrm{t}$ count $<\mathrm{t}$ table so that $\mathrm{Ha}$ is rejected, meaning the hypothesis that the variable type of work partially has no significant effect on the income of poor female heads of household in Madiun City was rejected.

\section{Elasticity Test}

Based on the results of the calculation of the elasticity test shows that the elasticity of the number of working hours is 1.116 , the value is greater than the others. This means that the variable number of working hours is elastic which means that the change in the number of working hours has a considerable influence on changes in income so that the variable number of working hours can be stated to have the most influence on the income of poor female heads of households in Madiun City.

\section{DISCUSSION}

\section{Influence of Education Level on Income of Female Family Heads}

Educational variables have a positive and significant effect on the income of poor female heads of households in Madiun City. This is consistent with Imron's (2015) finding that education has a positive and significant impact on the income of the head of the family. Suryahadi and Sumarto (2009) suggest that people with higher education will provide opportunities to get good jobs and high salaries. It can be said, that with proper education it will get a good job and get high income.

Although the education variable shows a significant influence following the opinions expressed by Suryahadi and Sumarto (2009) on income, in reality, the respondents lacked the quality of human resources because as many as 36 respondents or 36.74 percent of the total respondents only took elementary school education (SD). It can be said that the quality of education owned by the respondents is very minimal. So, in the end, the respondents only have relatively modest jobs, become domestic helpers, small-scale traders because of limited capital and the like.

\section{Influence of Age on Income of Female Family Heads}

Age variables do not significantly influence the income of low-income family heads in Madiun City. This finding is not in line with Nasir's (2008) finding that age has a positive and significant effect on the income of the head of the family. Based on the conditions in the field, the majority of respondents have an age above 50 years. This shows that this age is towards an unproductive age. This is also supported by the type of work done by respondents. The majority of respondents work with uncertain income such as laborers and the like whose wages are based on working hours or the number of units of goods that can be produced. Both of these reasons (non-productive respondents, and type of work), will affect the amount of income earned by respondents.

\section{The Influence of the Number of Working Hours on Income of Female Family Heads}

The number of working hours has a positive and significant effect on the income of poor female heads of households in Madiun City. Idris (2016) explains that someone who has a high amount of work time will increase the wages to be earned. This finding is in line with Wawansyah (2012) who 
argued that the number of working hours had a positive and significant effect on the income of the head of the family because by increasing the working hours' someone earns additional income.

Economic conditions are increasingly difficult sometimes forcing someone to get around in order to obtain additional income in order to cover their daily needs by increasing working hours (Chaer, 2010). This is because with more and more working hours it will increase one's income. In reality, the income of heads of poor women in Madiun City works as home industry craftsmen who are required to work many hours so that it will affect their work and increase their income.

\section{Influence of Number of Family Members on Income of Female Family Heads}

A large number of family members in the household reflects the number of dependents of the family head. This can affect the level of income per capita received by family members. The number of dependents in the household is likely to increase family income per capita if family members are assumed to work and generate income.

Variables in the number of family members have a positive and significant effect on the income of poor female heads of households in Madiun City. This is in line with Istiqlaliyah (2010) 's findings that the number of family members has a positive and significant effect on the income of the head of the family because some family members have worked to affect per capita income. Family members.

\section{Effect of Type of Family Work on Income of Female Family Heads}

The type of work in the family is a factor that can affect the opinion of the head of the family. The primary type of work in the family is the determining factor in the amount of income (and expenditure) received by the family; this is because each type of work has a different level of wages (Gounder in Aulia, 2012)

This type of work (industry and non-industry) does not have a significant effect on the income of poor female heads of household. This is not in line with Arya's findings (2013) in the study that the type of work has a positive and significant effect on the income of the head of the family. This is because the type of work done by the respondent is only a type of small-scale industrial work or a home industry whose income or wages are received under Wages Minimum Regional (UMR) so that the type of work does not affect the income of poor female heads of households in Madiun City.

\section{CONCLUSION AND IMPLICATION}

\section{Conclusion}

Based on the results of the study, it can be concluded, among others:

(1) Variables in the number of working hours, education, and the number of family members have a positive and significant effect on the income of the head of the family, while the variable age, type of work does not have a significant effect on the income of poor female heads of households in Madiun City.

(2) The variable with the most considerable influence on the income of the head of a poor woman in Madiun City is the number of hours worked.

\section{Implication}

Based on the conclusions, the implications that can be conveyed in this study are as follows:

(1) The results of the study revealed that the variable number of working hours, education level, and the number of family members had a positive influence on the income of poor female heads of households in Madiun City. Based on this, the regional government is expected to improve the quality of family members from poor households, especially those of school age, by providing educational scholarships so that they do not drop out of school. In order to improve their quality, at least they can get an education for 12 years or equivalent to high school / vocational school. The number of family members attending school and the higher the level of education can increase the opportunity to get a good job, which will later increase income. 
(2) The number of working hours has a positive influence on the income of poor female heads of households in Madiun City and is the most influential variable on income, from other variables such as education level and the number of family members. Based on this, the regional government is expected to provide assistance to conduct training so that the heads and members of low-income families have unique skills and expertise such as sewing and making food. One way is to optimize the role of the Vocational Training Center (BLK). If the head and low-income family members have the skills and expertise, the income earned by their working hours can be higher and if they do not have the skills and expertise.

\section{REFFERENCES}

Arsyad, Lincolin. (2010). Ekonomi Pembangunan, Edisi Kelima. Yogyakarta : Bagian Penerbitan STIE YKPN.

Arikunto, Suharsini. (2010). Prosedur Penelitian Suatu Pendekatan Praktik. Jakarta: PT. Rineka Cipta

Arya Dwiandana P, Nyoman Djinar S. (2013). Pengaruh Umur, Pendidikan, Pekerjaan Terhadap Keluarga Miskin di Desa Bebandem. E-jurnal Ekonomi Pembangunan Universitas Udayana, 2(4), 173-180. (diakses 24 Juli 2016)

Aulia. (2012). Pengaruh Pembiayaan Jual Beli, Pembiayaan Bagi Hasil, dan Rasio Non Performing Financing (NPF) terhadap Profitabilitas Bank umum Syariah di Indonesia. Jurnal Fakultas Ekonomi dan Bisnis. Universitas Brawijaya.

Badan Kependudukan dan Keluarga Berencana Nasional. (2011). Profil Hasil Pendataan Keluarga Tahun 2015. Jakarta: BKKBN Direktorat Pelaporan dan Statistik.

Badan Pusat Statistik Jakarta Pusat. (2015). Statistik Indonesia Tahun 2015. Pusat: Badan Pusat Statistik. Jakarta.

Badan Pembangunan Nasional. (2010). http://els.bappenas.go.id/

Chaer, Abdul dan Loenie Agustina. (2010). Sosiolinguistik: Perkenalan Awal. Jakarta: Rineka Cipta.

Gujarati, Damodar. (2008). Dasar-dasar Ekonometrika. Jakarta: Erlangga.

Idris, Amiruddin. (2016). Pengantar Ekonomi Sumber Daya Manusia. Yogyakarta: Deepublish.

Irawan\&Suparmoko, M. (2008). Ekonomika Pembangunan. Edisi keenam. Yogyakarta: BPFE UGM.

Jones, W. Huston. (1979). Determinants of financial structure: A new methodological approach. Journal of Finance, 43(1), 1-19.

Mufklihati, Istiqlaliyah, Hartoyo, Ujang Sumarwan, Ahmad Fahrudin, Herien Puspitawati. (2010). Kondisi Sosial Ekonomi dan Tingkat Kesejahteraan Keluarga: Kasus di Wilayah Pesisir Jawa Barat. Jurnal Ilm. Kel. \& Kons, 3(1), 1-10.

Jhingan, (2010). Ekonomi Pembangunan dan Perencanaan. Jakarta: Rajawali Press.

Jones, W. Huston. (1979). Determinants of financial structure: A new methodological approach. Journal of Finance, 43(1), 1-19.

Mudrajad Kuncoro. (2010). Masalah, Kebijakan, dan Politik, Ekonomika Pembangunan. Jakarta: Penerbit Erlangga.

M. Muh. Nasir, Saichudin dan Maulizar. (2008). Analisis Faktor-Faktor Yang Mempengaruhi Kemiskinan Rumah Tangga Di Kabupaten Purworejo. Jurnal Eksekutif, 5(4).

Wawansyah, Hendra, Iwang Gumilar dan Ankiq Taufiqurahman. (2012). Kontribusi Ekonomi Produktif Wanita Nelayan terhadap Pendapatan Keluarga Nelayan. Jurnal Perikanan dan kelautan, 3(3). 
Pusat Kajian Wanita dan Gender. (2012). Hak Asasi Perempuan Instrumen Hukum untuk Mewujudkan Keadilan Gender. Jakarta: Yayasan Pustaka Obor Indonesia.

Suharto, Edi. (2009). Kemiskinan dan perlindungan sosial di Indonesia (Menggagas model jaminan sosial Universitas Bidang Kesehatan). Bandung [ID]: Alfabeta.

Supranto, J. (2010). Analisis Multivariat. Arti dan Interpretasi. Jakarta: Rineka Cipta.

Suryahadi, A., D. Suryadarma, and S. Sumarto. (2009). The Effects of Location and Sectoral Components of Economic Growth on Poverty: Evidence from Indonesia. Journal of Development Economics 89, 109-17.

Tim Nasional Percepatan Penanggulangan Kemiskinan (TNP2K). (2010). Penganggulangan kemiskinan: situasi terkini, target pemerintah, dan progam percepatan. Jakarta. 